\title{
Dynamics of Land-Use and Vegetation Change Using NDVI and Transfer Matrix: A Case Study of the Huaihe River Basin
}

\author{
Fang Liu ${ }^{1,2}$, Tianling Qin ${ }^{2 *}$, Abel Girma ${ }^{1}$, Hao Wang ${ }^{2}$, Baisha Weng ${ }^{2}$, \\ Zhilei $\mathrm{Yu}^{2}$, Zhenlong Wang ${ }^{3}$ \\ ${ }^{1}$ College of Environmental Science and Engineering, Donghua University, Shanghai, China \\ ${ }^{2}$ State Key Laboratory of Simulation and Regulation of Water Cycle in River Basin, \\ China Institute of Water Resources and Hydropower Research, Beijing, China \\ ${ }^{3}$ Anhui and Huaihe River Institute of Hydraulic Research, Bengbu, China
}

Received: 11 September 2017

Accepted: 12 January 2018

\begin{abstract}
The Huaihe River Basin is located in-between the north-south climate transitional zone in China and is China's important congested area and production base. The land-use of the environment was occupied by the land-use for social and economics. This paper aims to have a comprehensive understanding about land-use and vegetation evolution of the basin over the past 30 years. In view of 5 years $(1985,1990$, 2000, 2005, and 2014) land-use data and remote sensing data about NDVI, land-use dynamic degree, and land-use transfer matrix were used to analyze the dynamics of land use. Spatial overlay was used to study vegetation change characteristics of the basin. The present study investigates the evolution trend of vegetation coverage based on spatial overlay analysis. We found that water bodies and urban lands of the basin increased during 1985-2014. On the other hand, the area of artificial vegetation, natural vegetation, and wetland were reduced. The impact was gradually increased by human intervention on various land use types. Overall vegetation coverage level shows deteriorative development, and distribution areas were discrete. The excellent vegetation coverage of natural vegetation and wetland didn't have obvious changes, but the high coverage significantly decreased. Taken as a whole, the natural vegetation coverage was reduced. The vegetation coverage level of artificial water in the land-use for social and economics had greatly increased, but the overall trend of vegetation coverage level of artificial vegetation and resident construction land showed a decreasing trend.
\end{abstract}

Keywords: Huaihe river basin, land-use, transfer matrix, vegetation change

*e-mail: tianling406@163.com 


\section{Introduction}

The modification of Earth's terrestrial surface by human activities is commonly known around the globe as land use/land cover change (LUCC) [1-3]. These changes are driving forces for unprecedented local, regional, and global changes in ecosystems and environmental processes [4-6]. Thus, LUCC changes play an important role in studying changes about global scenarios. Marcin et al. [7] analyzed the change in land-use regarding actual vegetation mapping and hemeroby concept adaptation of the Sokołówka River valley over 200 years; Meryem [8] et al. researched the land-use changes in relation to coastal tourism developments in the Turkish Mediterranean and found tourism development plans were accompanied by a set of ecological, social, and economic systems for the livelihood of tourism and the operated area; Michetti and Zampieri [9] provided a wide discussion of numerous types of applied models; Wei et al. [10] and Zhang [11] analyzed the land use change pattern and the major driving forces of the land use change in the Shiyang River Basin with Landsat/ETM data, population data, and economic statistical data.

The traditional land-use analysis method can only identify different land-use scale and structure, but it is impossible to identify evolution about each type of vegetation. The Huaihe River Basin is one of the major grain-producing areas where human activity has a major impact on the basin, so we need to focus on comprehensive evolution rules about ecological land (natural vegetation and wetland) and artificial land (artificial vegetation, artificial water area, and resident construction land) based on traditional land use identification. With the application of ArcGIS, this article used the traditional research methods to analyze spatial and temporal dynamic evolution of land-use and landscape pattern in the Huaihe River Basin. Land-use can reflect the function of soil and artificial water conservation. The vegetation coverage can reflect the growth condition of vegetation [12-14] as well as extract the normalized difference vegetation index of different land-use types to research the tendency of artificial watershed vegetation coverage. Quantitative evaluation of land-use and vegetation evolution is beneficial for identifying the new situation of land use and vegetation in the basin. It has a great significance to reasonably adjust land-use structure in the Huaihe River region and improve the efficiency of landuse and ecological environment.

\section{Study Area}

The Huaihe River Basin is located in eastern China. It crosses five provinces: Anhui, Henan, Jiangsu, Shandong, and Hubei. The study area is located between $111^{\circ} 56^{\prime} \mathrm{E} \sim 109^{\circ} 15^{\prime} \mathrm{E}$ and $30^{\circ} 57^{\prime} \mathrm{N} \sim 37^{\circ} 50^{\prime} \mathrm{N}$, and covers an area of $270,000 \mathrm{~km}^{2}$. The south area of the basin belongs to the subtropical zone while the northern area belongs to the warm temperate zone. It includes the Huaihe and Yishusi river systems (Fig.1).

The average precipitation of the Huaihe basin is about $880 \mathrm{~mm}$, and intra-annual and inter-annual precipitation changes greatly. The annual average temperature is about $13^{\circ} \mathrm{C} \sim 16^{\circ} \mathrm{C}$. Plains and hills are the dominant topography, with plains accounting for about $70 \%$ [15].

\section{Material and Methods}

\section{Data Source}

\section{Research Methods}

In this paper, the main data input includes 5 years (1985, 1990, 2000, 2005, and 2014) land-use data (1:100000), and normalized difference vegetation index

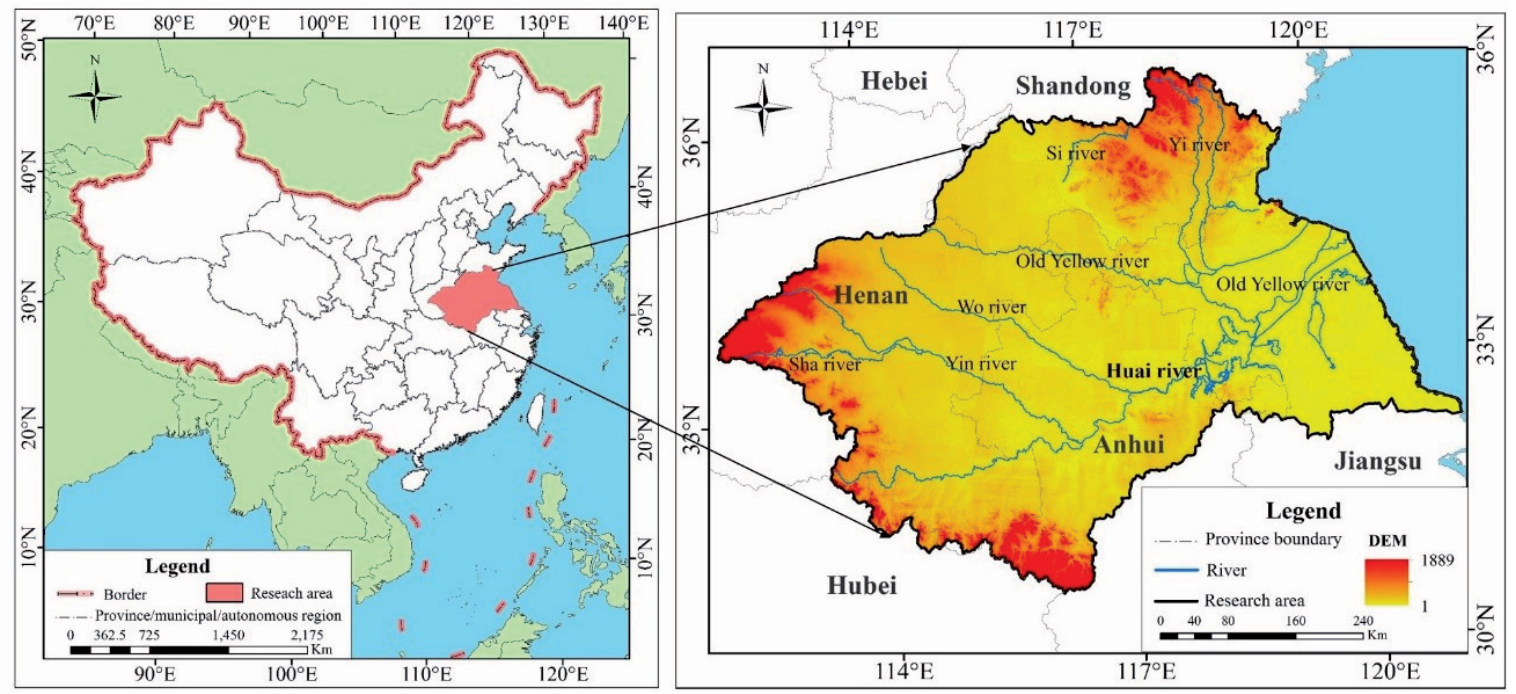

Fig. 1. Location of the Huaihe River Basin and drainage map with digital elevation model. 
Table 1. Reclassification of land use types in Huaihe River Basin.

\begin{tabular}{|c|c|c|}
\hline Number & Reclassification & Classification of the present land-use situation in China \\
\hline 1 & Artificial vegetation & Cultivated land, artificial grassland, and artificial forest \\
\hline 2 & Natural vegetation & Natural grassland and natural woodland \\
\hline 3 & Artificial water area & Reservoirs and swaps \\
\hline 4 & Wetland & Rivers, lakes, swamps, mudflats, and shoal \\
\hline 5 & Resident construction land & Urban and rural residents, industrial and mining land \\
\hline 6 & Others & Sand, gobi, saline-alkali land, bare land, etc. \\
\hline
\end{tabular}

(hereinafter referred to as NDVI) exacted by remote sensing image data from 1982 to 2014 and related vector files (from the national fundamental geographic information network-based data). In addition, DEM of the Huaihe Basin, administrative divisions, and basic geographic data of other countries were used as supplementary data. From NDVI remote sensing image data in 1982-2014, the data of 1982-2006 is GIMMS (the spatial resolution is $8 \mathrm{~km}$ ) and 2000-2014 is MODIS (the spatial resolution is $1 \mathrm{~km}$ ). According to the classification of the present land-use situation, we reclassified cultivated land, artificial grassland, and artificial forest as artificial vegetation. Natural grassland and natural woodland were reclassified as natural vegetation. Reservoirs and swamps were reclassified as artificial water bodies. Rivers, lakes, swamps, mudflats, and shoal were reclassified as wetland. Urban and rural residents and industrial and mining land were reclassified as resident construction land. Sand, gobi, saline-alkali land, and bare land, etc. were reclassified as other types (Table 1). Fig. 2 shows land-use types of the basin during 1985-2014.

Land use transfer matrix and ArcGIS 10.2 were employed to analyze a comprehensive land use dynamics degree [16]. Landscape pattern index was combined to analyze the fragmentation level of land-use type and human impact. The NDVI trend and land-use change were integrated to analyze the vegetation evolution characteristics.

1) Comprehensive land-use dynamic degree [16]

$$
L C=\frac{\sum_{\mathrm{i}=1}^{n} \mathrm{~V} L U_{i-j}}{2 \sum_{\mathrm{i}=1}^{n} L U_{i}} \times \frac{1}{T} \times 100 \%
$$

a)

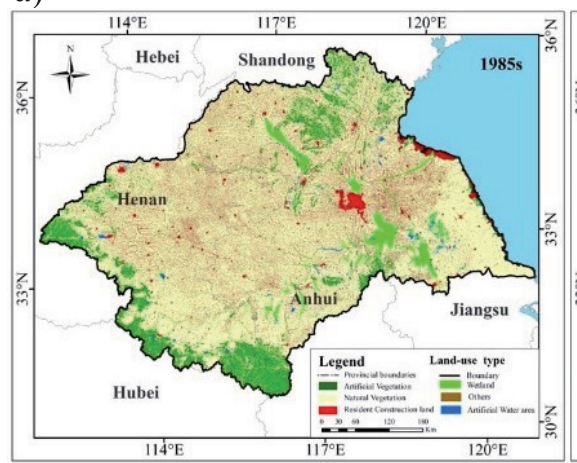

d)

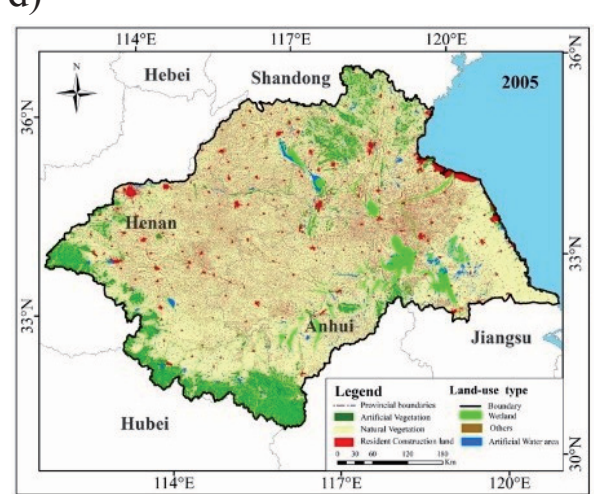

b)

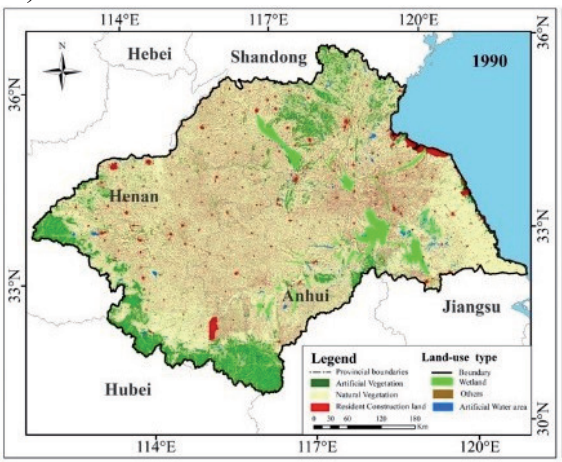

c)

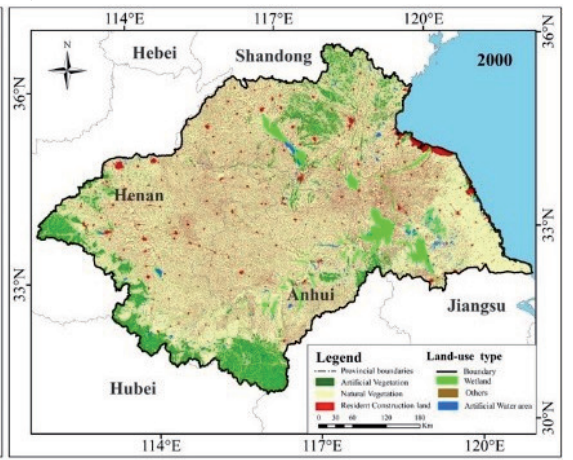

e)

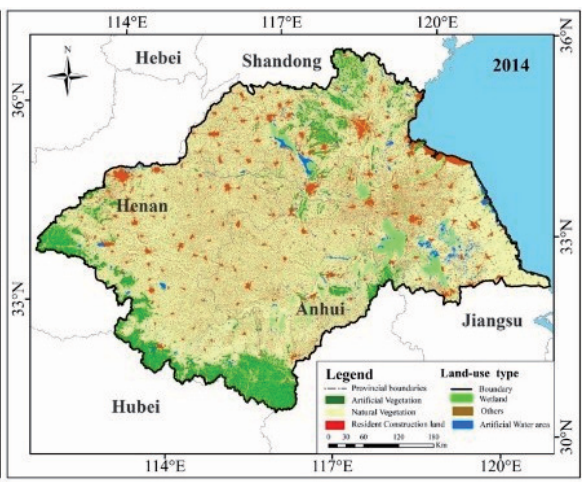

Fig. 2. Land use spatial distribution map of the Huaihe River Basin. a) 1985, b) 1990, c) 2000, d) 2005, e) 2014. 
Table 2. Corresponding distribution table of gray-scale value and vegetation coverage [17].

\begin{tabular}{|c|c|c|c|c|}
\hline Grade & $\begin{array}{c}\text { Gray-scale value } \\
\text { segmentation }\end{array}$ & $\begin{array}{c}\text { Percentage of } \\
\text { vegetation coverage }\end{array}$ & Land-use type & $\begin{array}{c}\text { Vegetation coverage } \\
\text { grade }\end{array}$ \\
\hline Level 1 & $191 \sim 255$ & $>60 \%$ & Dense shrub land, forest land, and shrub land, etc. & Excellent \\
\hline Level 2 & $156 \sim 190$ & $30 \% \sim 60 \%$ & $\begin{array}{c}\text { Good farmland, potential degraded land, high } \\
\text { coverage grassland, and forest land, etc. }\end{array}$ & Good \\
\hline Level 3 & $139 \sim 155$ & $15 \% \sim 30 \%$ & Middle plain grassland, fixed sand and beach, etc. & Medium \\
\hline Level 4 & $128 \sim 138$ & $5 \% \sim 15 \%$ & $\begin{array}{c}\text { Desert grassland, forest land, and scattered vegeta- } \\
\text { tion, etc. }\end{array}$ & Subalternation \\
\hline Level 5 & Less than 128 & Less than $5 \%$ & $\begin{array}{r}\text { Desert, gobi, artificial water areas, and residential } \\
\text { areas, etc. }\end{array}$ & Inferior \\
\hline
\end{tabular}

Table 3. Dynamic variation of land-use of the Huaihe River Basin in 1985 to 2014 (\%).

\begin{tabular}{|c|c|c|c|c|c|}
\hline Land-use type & $1985-1990$ & $1990-2000$ & $2000-2005$ & $2005-2014$ & $1985-2014$ \\
\hline Artificial vegetation & -0.55 & 0.15 & 0.2 & -1.03 & -1.31 \\
\hline Natural vegetation & 0.15 & 0.04 & -1.09 & -1.27 & -2.37 \\
\hline Artificial water area & 3.02 & 2.93 & 4.53 & 2.76 & 9.14 \\
\hline Wetland & -0.7 & 0.3 & -1.14 & 0.21 & -1.43 \\
\hline Resident construction land & 3.44 & 0.75 & -2.11 & 7.03 & 6.39 \\
\hline Others & 2.17 & -1.56 & -7.46 & 11.53 & 0.2 \\
\hline Comprehensive land-use dynamic degree (LC) & 0.42 & 0.13 & 0.32 & 0.55 & 0.45 \\
\hline
\end{tabular}

...where LC is the comprehensive land-use dynamic degree of the study area, $\mathrm{LU}_{i}$ is the area of type I land-use system from monitoring the starting time, $\mathrm{LU}_{\mathrm{i}-\mathrm{i}}$ is the absolute value of an area in land-use from type $i$ to $\mathrm{j}$ within monitoring time, and $\mathrm{T}$ is monitoring time. When $\mathrm{T}$ is set for years, $\mathrm{LC}$ is the land-use dynamic change rate in the study area.

2) We can get 5 groups of transfer matrix for the different land-use types, that is from 1985-1990, 1990-2000, 2000-2005, 2005-2014, and 1985-2014 to grasp the transfer situation of the basin.

3) Number of patches (NP), edge density (ED), and patch size (MPS) were used to analyze fragmentation degree of artificial watershed landscape. Areaweighted mean shape index (AWMSI) was employed to identify the complexity and irregularity of land use dynamics degree. It also reflects the influence of human activities on landscape structure.

4) Because of the different spatial resolutions between GIMMS and MODIS, based on MODIS data, we used the linear regression model to extend GIMMS data until 2014. We also used the same data series to check extend data. After the inspection, NDVI average correlation coefficient reached more than $90 \%$ in the basin. We further analyze the land-use type and the NDVI gray-scale value (Table 2) in order to evaluate the vegetation coverage evolution trend.

\section{Results and Discussion}

Temporal and Spatial Variation of Land-Use Evolution in the Huaihe Basin

In the present study, artificial and natural vegetation plus wetlands showed a decreasing trend by $12,098 \mathrm{~km}^{2}, 3,208 \mathrm{~km}^{2}$, and $640 \mathrm{~km}^{2}$, respectively, during 1985-2014, whereas the area of artificial water and resident construction land showed an increasing trend by $2,276 \mathrm{~km}^{2}$ and $3,690 \mathrm{~km}^{2}$ respectively. However, the other areas saw little change (Fig. 3).

For a single land-use type, the changing rate for artificial water bodies and resident construction land were larger during 1985-2014. The dynamic degree was $9.14 \%$ and $6.39 \%$, respectively, which showed increasing pattern on area coverage. The area of artificial vegetation, natural vegetation, and wetland decreased, and the changing rate was lower. The degree of interference to land use manner by human activities was larger during 2005-2014 compared to during 1985-1990, 19902000 , and $2000-2005$. The dynamic degree is $0.45 \%$ in 1985-2014, which indicated that $4.5 \%$ of the land use type had changed during this time every year (Table 3). During the early $21^{\text {st }}$ century, the population of the Huaihe Basin had a high growth rate when the per capita occupancy of land resources was low, which causes a paradox in land use to a certain extent [18]. 


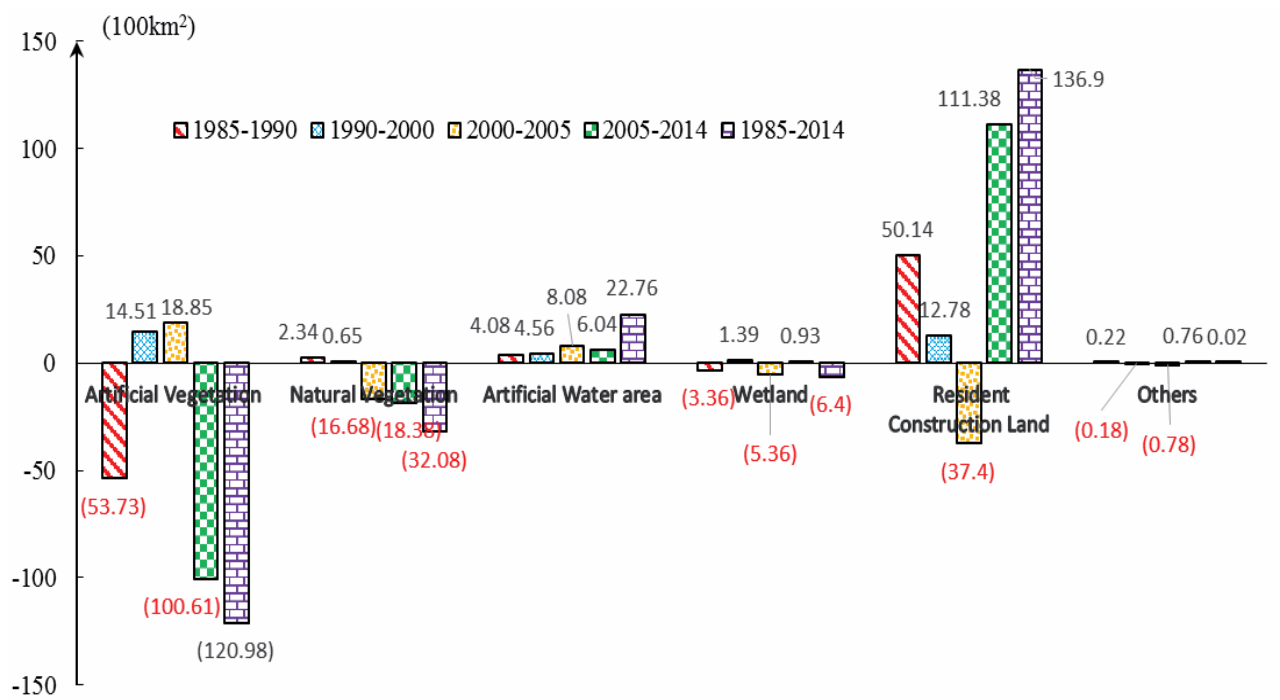

Fig. 3. Area change of land use of Huaihe River Basin, 1985 to 2014.

Various land-use types had shown a significant difference in the number and space composition in the basin. Land use type was mainly for artificial vegetation, natural vegetation, and resident construction land during 1985-2014, and the sum of area proportion was more than 94\%. Artificial water bodies and wetland distribution areas were relatively small, and their areas of proportion were about $1 \%$ and $3 \%$. The area coverage for others was smaller, and the proportion was less than $0.1 \%$ (Fig. 4).

From the transfer type of land-use space graph (Fig. 5), we can observe that the transfer area of land use type was mainly concentrated in the boundary of the basin area: Nansi Lake Basin within Shandong and Suqian within the territory of Jiangsu during 1985-2014 in the Huaihe Basin. Between 1985-1990 and 1990-2000, land-use type transfer area was mainly concentrated in Henan and Jiangsu. In 2005-2014 the agglomeration density was concentrated in the territory of Shandong Province. There was a great land-use change in 2005-
2014 compared to other years. In 2005-2014 a portion of land was transformed into urban land with a discrete distribution pattern.

Each single land-use type space shift change was mainly artificial and natural vegetation change to the rest of the four types of land-use type during 1985-2014. The reciprocal transformation between the four types was not obvious. More than a one third of artificial vegetation transformed into resident construction land and artificial water bodies. More than $30 \%$ of natural vegetation is converted into other types of land such as sand, salinealkali land, and bare land (Table 4). The main reasons for the changes are rapid population growth, high-intensity socio-economic activities, urbanization, and ecological deterioration in the research region [19].

From the plaque index dynamic change characteristics (Table 5), the ED and MPS of natural vegetation, wetland, and others land use types showed small fluctuations during 1985-2014. The NP increased in 1990 and 2005.

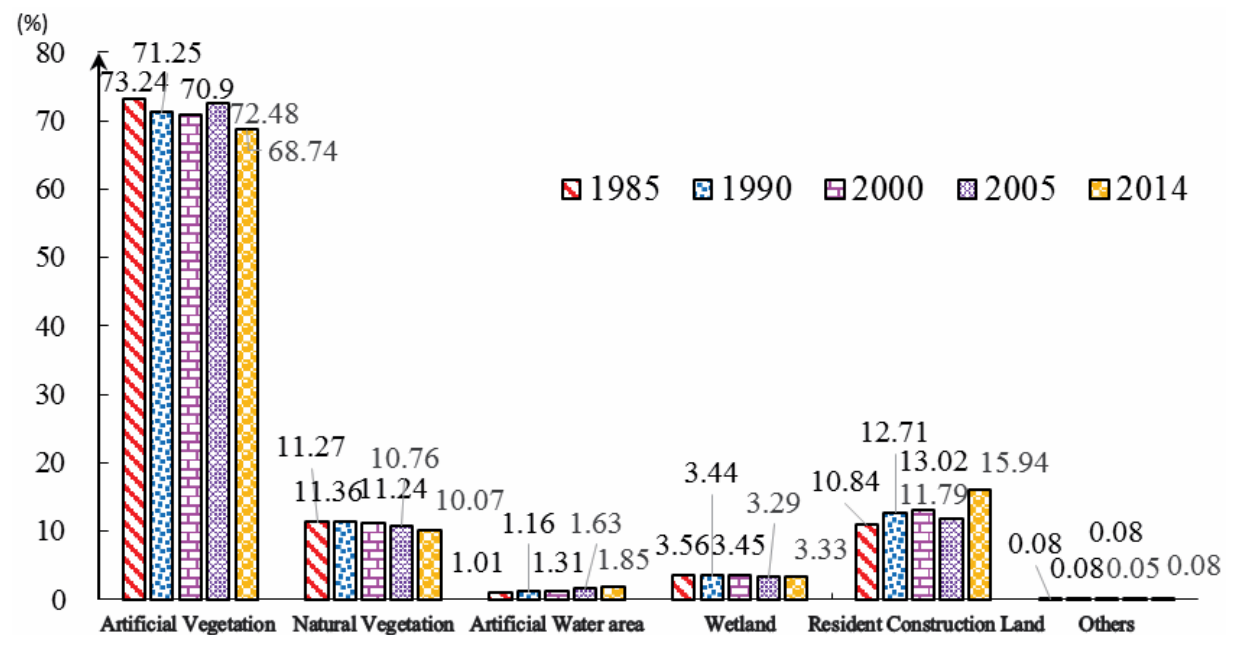

Fig. 4. Area change of land use of the Huaihe River Basin, 1985 to 2014. 
a)

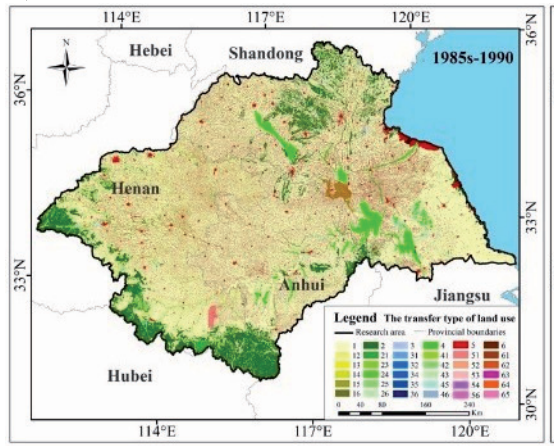

d) b)

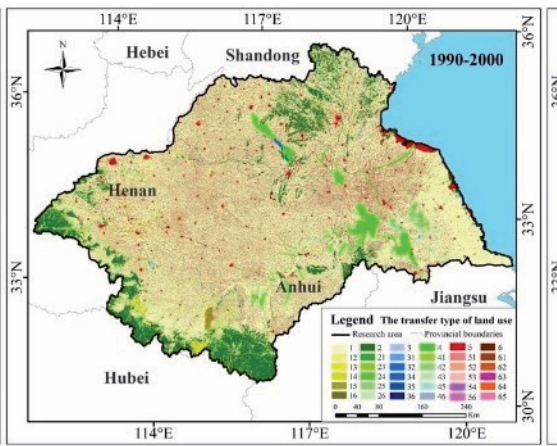

c)

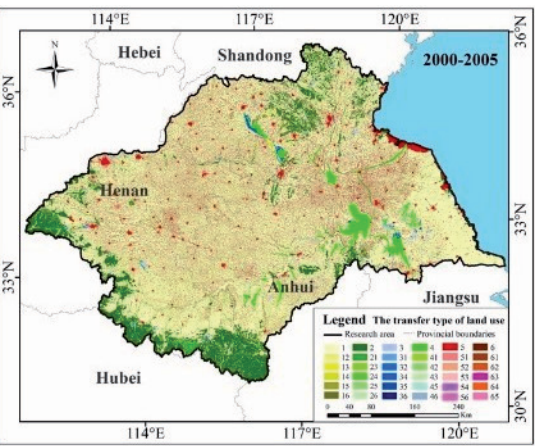

e)

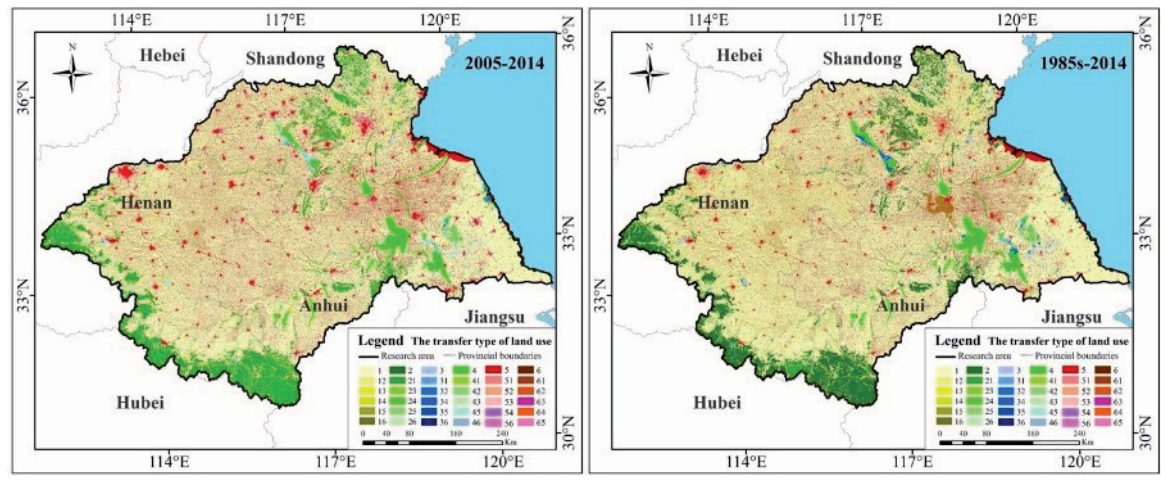

Fig. 5. Spatial transformation variation map of land-use type of the Huaihe River Basin. a) 1985-1990, b) 1990-2000, c) 2000-2005, d) 2005-2014, e) 1985-2014.

Annotation: 1- Artificial vegetation 12- Transfer artificial vegetation to natural vegetation 13- Transfer artificial vegetation to artificial water area 14- Transfer artificial vegetation to wetland 15- Transfer artificial vegetation to resident construction land 16- Transfer artificial vegetation to others 2-natural vegetation 21- Transfer natural vegetation to artificial vegetation 23-Transfer natural vegetation to artificial water area 24- Transfer natural vegetation to wetland 25- Transfer natural vegetation to resident construction land 26- Transfer natural vegetation to others 3- Artificial water area 31- Transfer artificial water area to artificial vegetation 32- Transfer artificial water area to natural vegetation 34- Transfer artificial water area to wetland 35- Transfer artificial water area to construction 36- Transfer artificial water area to others 4- Wetland 41- Transfer wetland to artificial vegetation 42- Transfer wetland to natural vegetation 43- Transfer wetland to artificial water area 45- Transfer wetland to resident construction land 46- Transfer wetland to others 5- Resident construction land 51- Transfer resident construction land to artificial vegetation 52- Transfer resident construction land to natural vegetation 53- Transfer resident construction land to artificial water area 54- Transfer resident construction land to wetland 56- Transfer resident construction land to others 6- Others 61- Transfer others to artificial vegetation 62- Transfer others to natural vegetation 63- Transfer others to artificial water area 64- Transfer others to wetland 65- Transfer others to resident construction land.

After 2005 the NP returned to a level in 1985, and becomes relatively stable. Therefore, the fragmentation of landuse spatial distribution of wetland, natural vegetation, and others was small, and their distribution pattern was concentrated. The NP and ED of artificial vegetation, artificial water bodies and resident construction land increased, whereas the MPS had a small change, which indicated that the amount of plaque increased and the fragmentation degree had become higher. The AWMSI of all land-use types decreased during 1985-2000,

Table 4. Land-use transformation matrix of the Huaihe River Basin from 1985 to 2014 (\%).

\begin{tabular}{|c|c|c|c|c|c|c|}
\hline Land-use type & $\begin{array}{c}\text { Artificial } \\
\text { vegetation }\end{array}$ & $\begin{array}{c}\text { Natural } \\
\text { vegetation }\end{array}$ & $\begin{array}{c}\text { Artificial water } \\
\text { area }\end{array}$ & Wetland & $\begin{array}{c}\text { Resident } \\
\text { construction land }\end{array}$ & Others \\
\hline Artificial vegetation & 93.541 & $\underline{2.269}$ & 0.121 & 0.447 & $\mathbf{3 . 5 8 8}$ & 0.034 \\
\hline Natural vegetation & $\mathbf{7 . 4 4}$ & 91.82 & 0.208 & $\underline{0.264}$ & 0.202 & 0.065 \\
\hline Artificial water area & $\mathbf{3 1 . 0 8 6}$ & 6.071 & 42.135 & $\underline{15.643}$ & 5.03 & 0.035 \\
\hline Wetland & $\mathbf{8 . 2 2 2}$ & 1.434 & $\underline{2.195}$ & 87.362 & 0.775 & 0.012 \\
\hline Resident construction land & $\mathbf{4 5 . 9 8 4}$ & $\underline{1.682}$ & 0.299 & 0.305 & 51.668 & 0.062 \\
\hline Others & $\underline{11.843}$ & $\mathbf{3 6 . 9 7 8}$ & 0.055 & 0.079 & 4.709 & 46.337 \\
\hline
\end{tabular}


Table 5. Four plaque indices in land-use type of the Huaihe River basin, 1985 to 2014.

\begin{tabular}{|c|c|c|c|c|c|}
\hline \multirow{2}{*}{ Land-use type } & Plaque index & \multirow{2}{*}{$\begin{array}{c}\text { Number of patches } \\
\text { (NP) }\end{array}$} & \multirow{2}{*}{ Edge density (ED) } & \multirow{2}{*}{$\begin{array}{l}\text { Mean patch size } \\
(\text { MPS })\left(\mathrm{km}^{2}\right)\end{array}$} & \multirow{2}{*}{$\begin{array}{c}\text { Area-weighted } \\
\text { mean shape index } \\
(\text { AWMSI) }\end{array}$} \\
\hline & Years & & & & \\
\hline \multirow{5}{*}{ Artificial vegetation } & 1985 & 11,333 & 16.88 & $1,736.91$ & 30.57 \\
\hline & 1990 & 13,418 & 20 & $1,426.98$ & 42 \\
\hline & 2000 & 16,887 & 21.37 & $1,142.44$ & 15.75 \\
\hline & 2005 & 11,431 & 17.15 & $1,704.21$ & 30.57 \\
\hline & 2014 & 12,906 & 20.4 & $1,431.48$ & 37.25 \\
\hline \multirow{5}{*}{ Natural vegetation } & 1985 & 19,785 & 5.7 & 153.27 & 6.2 \\
\hline & 1990 & 29,392 & 6.66 & 103.83 & 7.07 \\
\hline & 2000 & 27,779 & 6.23 & 110.09 & 5.01 \\
\hline & 2005 & 17,228 & 5.15 & 167.83 & 7.5 \\
\hline & 2014 & 19,326 & 5.18 & 140.1 & 6.52 \\
\hline \multirow{5}{*}{$\begin{array}{l}\text { Artificial water } \\
\text { areas }\end{array}$} & 1985 & 3,869 & 0.64 & 69.82 & 3.18 \\
\hline & 1990 & 10,495 & 0.91 & 29.63 & 3.02 \\
\hline & 2000 & 11,776 & 0.98 & 30.28 & 2.77 \\
\hline & 2005 & 4,531 & 0.83 & 96.52 & 3.33 \\
\hline & 2014 & 15,629 & 1.24 & 31.85 & 2.96 \\
\hline \multirow{5}{*}{ Wetlands } & 1985 & 2,273 & 1.7 & 421.42 & 7.98 \\
\hline & 1990 & 3,033 & 1.56 & 304.76 & 7.27 \\
\hline & 2000 & 4,267 & 1.84 & 219.87 & 4.73 \\
\hline & 2005 & 1,888 & 1.61 & 468.52 & 8.79 \\
\hline & 2014 & 2,783 & 1.65 & 321.19 & 7.75 \\
\hline \multirow{5}{*}{$\begin{array}{c}\text { Resident } \\
\text { construction lands }\end{array}$} & 1985 & 95,924 & 8.95 & 30.38 & 2.44 \\
\hline & 1990 & 178,601 & 12.05 & 19.12 & 1.63 \\
\hline & 2000 & 180,283 & 12.23 & 19.65 & 1.63 \\
\hline & 2005 & 95,665 & 9.3 & 33.13 & 1.85 \\
\hline & 2014 & 193,852 & 14.21 & 22.1 & 2.06 \\
\hline \multirow{5}{*}{ Others } & 1985 & 360 & 0.06 & 57.05 & 2 \\
\hline & 1990 & 474 & 0.07 & 48.03 & 2.01 \\
\hline & 2000 & 484 & 0.06 & 43.37 & 2.03 \\
\hline & 2005 & 276 & 0.04 & 47.69 & 1.96 \\
\hline & 2014 & 377 & 0.05 & 55.04 & 2.28 \\
\hline
\end{tabular}

but increased during 2005-2014, which indicated that a complex shape and irregular degree of land-use type decreased during 1985-2000 and increased during 2005-2014. Through the period of 1990-2000, converting farmland to forest vegetation restoration project was the main factor that reduces the impact of human beings on different land use types. However, since the 21 st century China has entered a new era of rapid urbanization development. Meanwhile, industrialization and mining activities were largely intensified, which in turn causes a significant change toward the different land-use types [20-21].

Vegetation is connected to the natural factors such as atmosphere, soil, and artificial water bodies, etc. The spatial pattern of vegetation does not only affect the ecosystem structure and function, but can also impact soil erosion and artificial water loss patterns [2223]. During 1985-2014, the area of different vegetation coverage levels increased in urban areas and artificial water bodies. Lots of industrial and domestic waste 
were discharged into reservoir and swag due to the development of industry and agriculture in the Huaihe Basin (Fig. 6). Chemical fertilizers, pesticides, and bait of agriculture, animal husbandry, and fisheries contributed to the increased eutrophication of the water bodies [24]. The area of wetland, artificial, and natural vegetation decreased, and the excellent coverage level didn't change obviously, but good coverage significantly decreased. So the vegetation coverage was reduced - especially the area of inferior coverage, which increased by $80 \%$. This implies that vegetation coverage of dominance in natural wetland degenerated, resulting in matches with $\mathrm{Xu}$ LiLi's [25] findings. She put forward that the area of wetlands increased totally, but the scale of the natural wetlands such as swamp dropped significantly.

During 1985-2014 the area of preponderant vegetation coverage in NDVI $>0.6$ increased by $76 \%$, mainly in Henan Province. Precipitation has been increasing year by year around the Huaihe Basin [26]. During this period the vegetation gets enough water for growth. In 2000 the vegetation coverage level had been greatly reduced and the percentage of preponderant coverage area accounted for only about $8.66 \%$ of the research area. This was mainly because the total annual precipitation was reduced [27]. During 2005-2014 the area of preponderant vegetation coverage in NDVI $>0.6$ was reduced by $30 \%$, but the area of inferior vegetation coverage lower than 0.4 was
The area change of different vegetation coverage about artificial vegetation in Huai river basin during 1985-2014

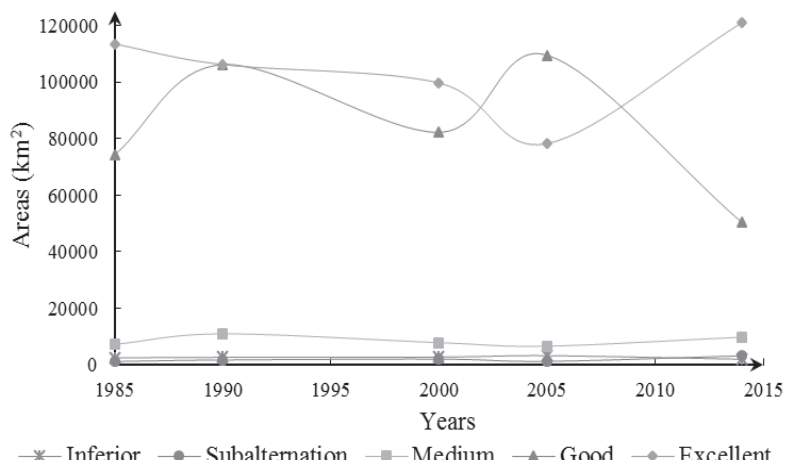

The area change of different vegetation coverage about artificial water in Huai river basin during 1985-2014

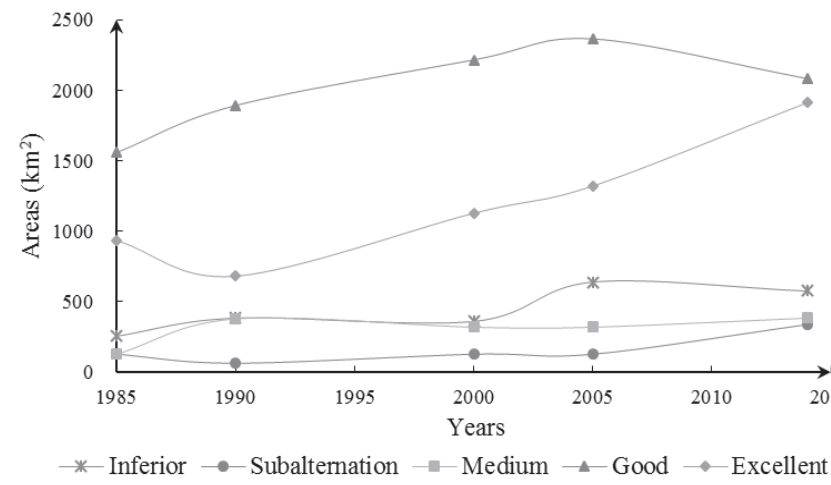

The area change of different vegetation coverage about resident construction land in Huai river basin during 1985-2014

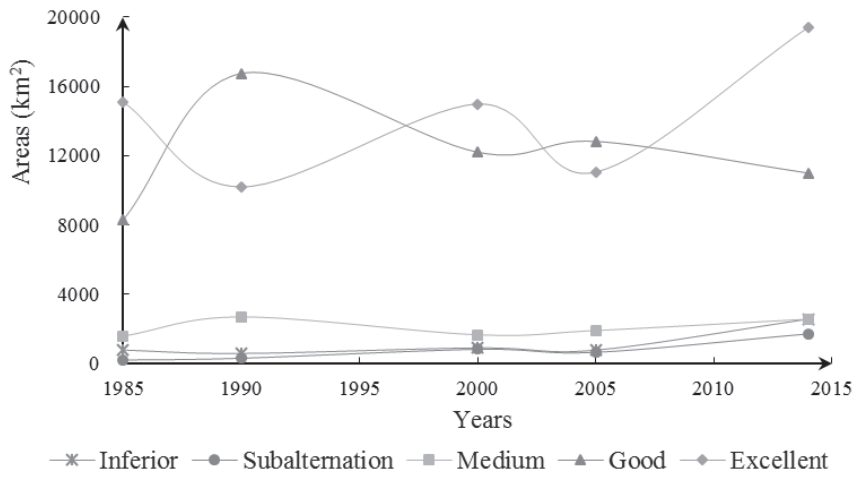

The area change of different vegetation coverage about natural vegetation in Huai river basin during 1985-2014

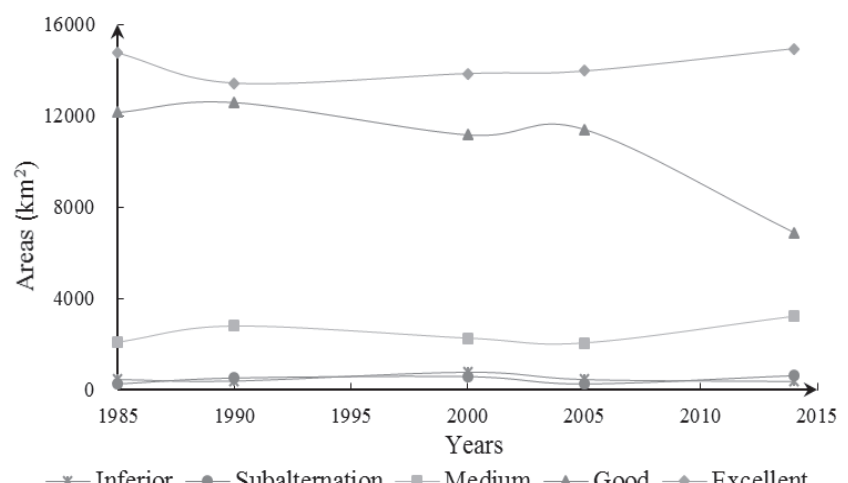

The area change of different vegetation coverage about wetland in Huai river basin during 1985-2014

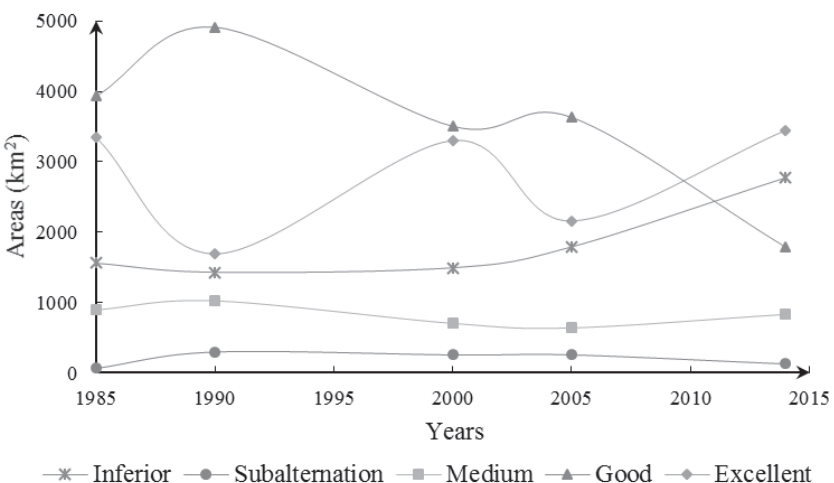

Fig. 6. Area change of different vegetation coverage for all land use types, 1985-2014 . 
a)

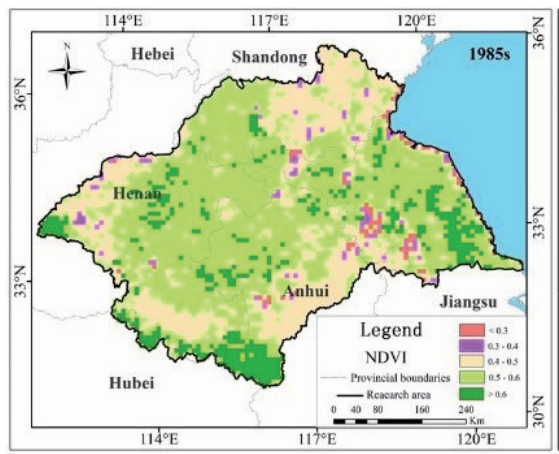

d)

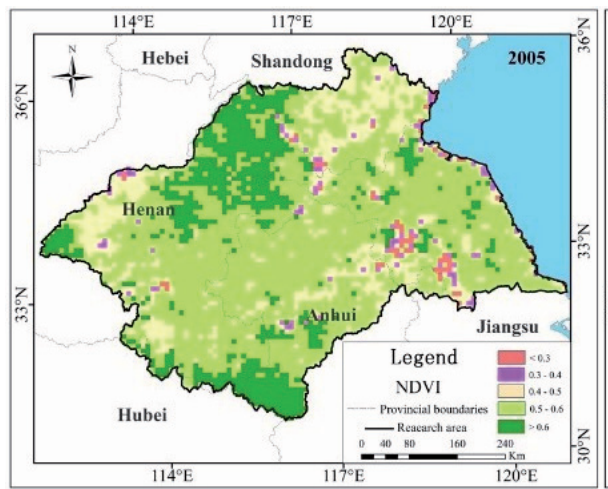

c)
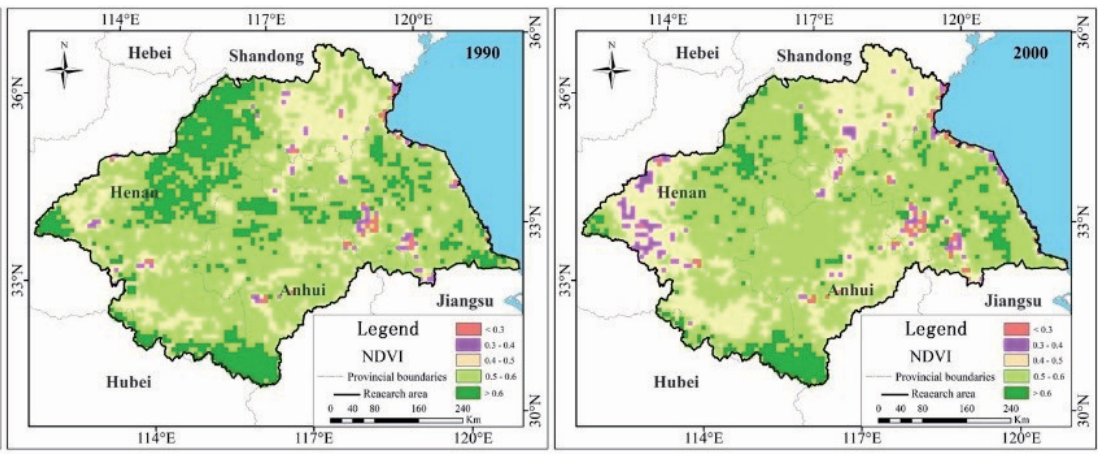

e)

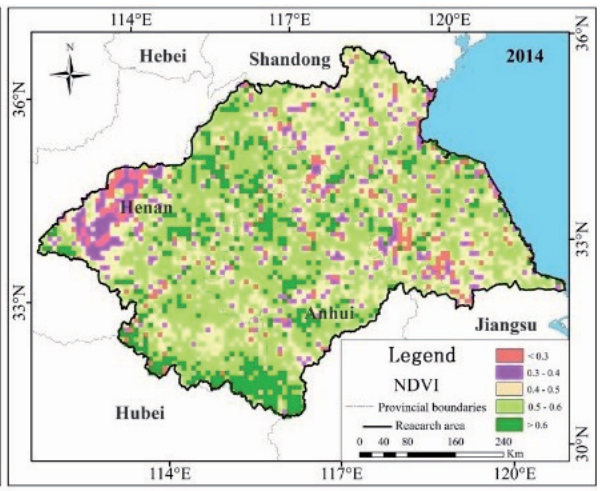

Fig. 7. Spatial distribution map of the NDVI. a) 1985, b) 1990, c) 2000, d) 2005, e) 2014.

increased by $75 \%$. The main reason for the vegetation increment was that precipitation during the summer season increased [28] and harsh climatic conditions were reduced, which created favorable conditions for plant growth [29] in this period. Conversely, urbanization led it to follow a scattered pattern (Fig. 7).

\section{Conclusions}

This paper used 5 years $(1985,1990,2000,2005$, and 2014) of land-use data and NDVI in the most recent 30 years. An ArcGIS platform and remote sensing were used to analyze the spatial and temporal evolution of land use and vegetation characteristic use. Conclusions are:

1) In 1985-2014, artificial water bodies and land for construction increased in time and space among various land use types. Due to high socio-economic activities, the areas for wetlands and artificial and natural vegetation were reduced. The main driving force of the changes was growth of the residential construction industry, trade areas, and transportation infrastructure [30-31]. During 1985-1990 the investment in fixed assets was increased and a largerscale development zone was built, which made a great contribution for increment of urban industrial and mining land. In 1990-2000, China issued six major forestry planning project for repairing ecological deterioration, and this policy controlled the intensification of urbanization over a period of time [18]. But after 2000, further economic development accelerated the urbanization level [19], which led to a great reduction of both artificial and natural vegetation in the study area.

2) During 1985-2014, overall vegetation coverage level showed a decreasing pattern, and distribution was discrete in the region. The vegetation coverage levels increased in urban areas and artificial water bodies. The land-use areas were decreased in artificial, natural vegetation, and wetlands, and the excellent coverage didn't obviously change. Extreme precipitation can make a big impact on vegetation growth [32-33], and extreme rainfall indirectly changes plant growth by changing soil moisture [34]. The frequency of extreme precipitation was decreased and the extreme minimum temperature increased while the extreme maximum temperature during 1985-2014 decreased [35-38]. Although the vegetation coverage condition was in an increasing trend in this period, the occurrence of urbanization in the study area primes to degradation and uneven distribution in respect to vegetation coverage.

With the unique geographical location of the Huaihe River Basin, the demand for land-use becomes increasingly higher during different periods. The impact of land use change on the NDVI mechanism should be discussed in the future. 


\section{Acknowledgements}

This study was supported by the National Key Research and Development Project (No. 2016YFA0601503, NO. 2017YFA0605004), the Representative Achievements and Cultivation Project of State Key Laboratory of Simulation and Regulation of Water Cycle in River Basin (No. 2016CG02), and the Chinese National Natural Science Foundation (No. 51725905, NO.51409267).

\section{Conflict of Interest}

The authors declare no conflict of interest.

\section{References}

1. MOONEY H.A., DURAIAPPAH A., LARIGAUDERIA A. Evolution of natural and social science interactions in global change research programs. PNAS, 110 (1), 3665, 2013.

2. STERLING S.M., DUCHARNE A., POLCHER J. The impact of global land-cover change on the terrestrial artificial water cycle. Nature Climate Change, 3 (4), 385, 2012.

3. BIČÍK I., HIMIYAMA Y., FERANEC J., KUPKOVÁ L. Land use/cover changes in selected regions in the world - IX. IGU Commission on LUCC, Charles University in Prague: Prague, 2014.

4. BÜRGI M., STRAUB A., GIMMI U., SALZMANN D. The recent landscape history of Limpach valley, Switzerland: Considering three empirical hypotheses on driving forces of landscape change. Landscape Ecology, 25, 287, 2010.

5. DRUGA M., FALTAN V. Influences of environmental drivers on land cover structure and its long-term changes: A case study of the villages of Malachov and Podkonice in Slovakia. Moravian Geographical Reports, 22, 29, 2014.

6. SCHALDACH R., ALCAMO J., KOCH J., KOELKING C., LAPOLA D.M., SCHUENGEL J., PRIESS J.A. An integrated approach to modelling land-use change on continental and global scales. Environmental Modelling \& Software, 26, 1041, 2011.

7. KIEDRZYŃSKI M. et al. Analyzing the change in landuse about actual vegetation mapping and hemeroby concept adaptation of the Sokołówka River valley during 200 years. Polish Journal of Environmental Studies, 23(1), 109, 2014.

8. MERYEM A., TÜRKER A., MUSTAFA A. Land use changes in relation to coastal tourism developments in Turkish Mediterranean. Polish Journal of Environmental Studies, 19 (1), 21, 2010.

9. MICHETTI M., ZAMPIERI M. Climate-Human-Land interactions: A review of major modelling approaches. Land, 3 (3), 793, 2014.

10. WEI W., XIE Y.W., SHI P.J., ZHOU J.J., LI C.H. Spatial temporal analysis of land use change in the Shiyang River Basin in arid China 1986-2015. Polish Journal of Environmental Studies, 26 (4), 1789, 2017.

11. ZHANG S.Q., AN F.Z., GUO Y.F. Research on land use change of Shiyang River Basin based on TM image. Environmental Protection of Xinjiang. 34 (1), 40, 2012.

12. NAZILA K. Evaluation of land use to decrease soil erosion and increase income. Polish Journal of Environmental Studies, 23 (4), 1329, 2014.

13. CHENG S.D., LI Z.B., LU K.X. Spatio-temporal variations in vegetation coverage and correlation with geomorphologic factors in Wenanyi watershed. Jouranl of Xi'an University of Technology, 27 (2), 145, 2011.

14. JIANG W.G., YUAN L.H., WANG W.J. Spatio-temporal analysis of vegetation variation in the Yellow River Basin. Ecological Indicators, 51, 117, 2015.

15. Ministry of Huaihe river artificial water resources commission of artificial water resources, Brief History of Huaihe River Artificial water Resources. Artificial water Resources and Electric Power Press: Beijing, China, 1996 [In Chinese].

16. ZHANG L., YANG G.F., LIU J.P. The dynamic changes and hot spots of land use in fushun city from 1986 to 2012. Scientia Geographica Sinica, 34 (2), 185, 2014.

17. ZHOU Z.Y., CHU S.L, WANG Z.W. Analysis of vegetation coverage change based on NDVI-A case study in Ganzhou area, Zhangyecity, Gansu. Grassland science, 25 (12), 23, 2008.

18. GUI J., ZHAO H.L., ZHAN W. Impact of land-use induced changes on agricultural productivity in the Huang-HuaiheHai River Basin. Physics and Chemistry of the Earth, 79 (82), 86, 2015.

19. XING W., HU X.L., ZHANG R.H. Control effects of the national key project of soil and water conservation on the soil erosion in Huaihe River Basin. Science of Soil and Water Conservation, 14 (2), 137, 2016.

20. LIU J.Y., KUANG W.H., ZHANG Z.X. Spatiotemporal characteristics, patterns and causes of land use changes in China since the late 1980s. ACTA GEOGRAPHICA SINICA, 1 (1), 3, 2014.

21. LIU J.Y., LIU M.L., ZHUANG D.F. Study on spatial pattern of land-use change in China during 1995-2000. Science in China Press. 46 (4), 2003.

22. CROK B.F.W., REITT WS, JAKEMAN A.j. A dynamic model for predicting hydrologic response to land cover changes in gauged and ungauged catchments. Journal of Hydrology, 291 (1), 115, 2004.

23. WANG G., JIANG H., XU Z. Evaluating the effect of land use changes on soil erosion and sediment yield using a grid-based distributed modelling approach. Hydrological Processes, 26 (23), 3579, 2012.

24. CHEN X., ZHANG Y.P. Land use change of China based on NDVI and landscape ecology [J], IITA-GRS, 2, 540, 2010.

25. XU L.L. WAN Y., SHENG S. Characteristics, hotspots and influencing factors of wetland change in Huaihehe river basin. Journal of Natural Resources, 28 (8), 1383, 2013.

26. LIANG L., ZHAO L.A., GONG Y.F. Probability distribution of summer daily precipitation in the Huaihe Basin of China based on gamma distribution. ACTA METEOROLOGICAL SINICA, 26 (1), 72, 2012.

27. YANG M., CHEN X., CHENG C.S. Hydrological impacts of precipitation extremes in the Huaihe River Basin, China. Springerplus, 5 (1), 1731, 2016.

28. SHE D.X., XIA J., ZHANG Y.Y., DU H. The trend analysis and statistical distribution of extreme rainfall events in the Huaihe River basin in past 50 years. ACTA GEOGRAPHICA SINICA, 66 (9), 1200, 2011. 
29. WANG K.Q., ZENG Y., XIE Z.Q. Chang trend of temperature and precipitation in Huaihe river basin from 1961-2008. Journal of the Meteorological Sciences, 32 (6), 671, 2012.

30. POŁAWSKI Z. Land use changes in Poland during last two centuries. Teledetekcja środowiska, 42, 69, 2009 [In Polish].

31. GASIOROWSKI J., POŁAWSKI Z. Land use structure as the basis for indicators determining spatial development of the environment. Polish Journal of Environmental Studies, 23, 955, 2014.

32. MBEREGO S. Temporal patterns of precipitation and vegetation variability over Botswana during extreme dry and wet rainfall seasons. International Journal of Climatology, 53 (12), 2016.

33. YAN D., XU T., GIRMA A. Regional Correlation between Precipitation and Vegetation in the Huang-Huai-Hai River Basin, China. Water, 9 (8), 557, 2017.
34. ZEPPEL M.J.B., WILKS J.V., LEWIS J.D. Impacts of extreme precipitation and seasonal changes in precipitation on plants. Biogeosciences, 11 (11), 3083, 2014.

35. YAO M.T., GAO C., LU M. The intensity and frequency characteristics of extreme runoff over the Huaihe River Basin during 1959-2008. GROGRAPHICAL RESEARCH 34 (08), 1535, 2015.

36. YANG M., CHEN X., CHENG C.S. Hydrological impacts of precipitation extremes in the Huaihe River Basin, China. Springerplus, 5 (1), 1731, 2016.

37. DU H., XIA J., ZENG S.D. Regional frequency analysis of extreme precipitation and its spatio-temporal characteristics in the Huaihe River Basin, China. Natural Hazards, 70, 195, 2014.

38. ZHANG D.D., YAN D.H., WANG Y.C. Changes in extreme precipitation in the Huang-Huaihe-Hai River basin of China during 1960-2010. Theoretical and Applied Climatology, 120, 195, 2015. 
